DOI https://doi.org/10.36059/978-966-397-108-7/185-204

\title{
EVOLUTION OF THE CONCEPTIONS OF SPACE AND TIME STRUCTURES' REFLECTION IN THE EUROPEAN TRADITION OF HISTORIOGRAPHY
}

\section{Chekanov V. Yu.}

\section{INTRODUCTION}

The historical science of modern times functions over 80 years already in the shade of French "Ècole des Annales". Since 1929 it was considered an avant-garde of the most progressive trends in it, and never lost this status. This school is highly appreciated and regarded not only for its groundbreaking penetration into the research fields previously neglected by historians but also for its creation of generalizing conceptions of the past helping mankind to orientate itself in the space and time of the past ${ }^{1}$.

The philosophical approach of the school wasn't anything totally unpredictable but mainly continuing and developing the way of research outlined by Dutch historian Johann Huizinga in his work "The Autumn of the Middle Ages" (1919) ${ }^{2}$. From the very start it was threw in the field of cultural history and historiosophy never tied with historical science so tightly as from that time. In the period before history dared seldom to speak so freely about common trends of European civilization.

Previously patriotically motivated and only partly belonging to the human race on whole, the historical science gradually moves since then up to the phase where just general history ("world history") exists. The starting point was the ambitious attempt to prove the truly scientific character of history in the times when positivistic approach dominated and natural sciences were appreciated the highest. They provided the most important advancements during the period of arms race, and, of course, there was no idea that new ways of mankind's self-identification towards the past would ever be of the same meaning.

However the things have changed dramatically after the world wars' period was over in the mid XX century. Since that time the significance of

\footnotetext{
${ }^{1}$ Февр Люсьен. Бои за историю, Р. 25-38.

${ }^{2}$ Хёйзинга Йохан. Осень Средневековья. Р. 5, 8-10, 344-345, 575.
} 
"Ècole des Annales" spreads not just fulfilling the need for research methods in medievistics; now the totality of its methodology helps historians to find themselves in the entire system of the world and of knowledge in the widest meaning of the world ${ }^{3}$.

The prominent scientists of the school were quite aware of it and never negated these ambitions as non-realistic. We think that the cornerstone is here the combination of history and historiography; patriotically motivated history never accepted fully the idea of its dependence upon the ways of representation of the past. Nationally oriented historiography is always out of doubt providing the picture where all the parts remain still. The meaning of it is just to make us know "more" about the things we cannot misunderstand; the new science doubts this approach stating we are in the space and time of entirely unknown meaning. To get strictly to the point is to find common parameters for the mankind on whole.

For instance, some research subjects like wars or revolutions still exist in the public consciousness of different nations represented there in different ways: sometimes as "revolutions", sometimes as "rebellions" (depending upon the social order behind these formulas). This kind of representation is heavily backed by non-historical reasons and hardly deserves to be considered scientific. Its correct re-consideration is possible only if non-historical motivation changes after some crucial moves in policy or if truly scientific view point surpasses previous ways of representation. The tradition commonplace in Russia - to give the defend wars on its territory title "patriotic" - is good example here. The war of 1812 is from the global view point an integral part of war of $6^{\text {th }}$ anti-Napoleonic coalition against imperial France, and the war of 1941-1945 is part of World War II.

Other subjects like revolutions change their meaning even more often, when the uprisings first hailed as "revolutions" then turn into "rebellions" and "coups d'ètat". It happens partly due to the dominance of opposite political tendencies but sometimes because the true size of events becomes visible from some impartial position which is ought to be the position of scientific research. The gradually increasing role of this position marks the most important trend in modern historiography; this

\footnotetext{
${ }^{3}$ Февр Люсьен. Ор. cit., Р. 17-23.
} 
process is possible due to the incorporation of the principles of "Ècole des Annales" in humanities.

Last but not least is to underline here that it is possible through historiography only because it never negates any patriotic motivation of research but opposes them on the methodological level where they make stand like modern item against outdated ones.

The significant feature is the actualization of historical research. It is possible via public request only and this request creates the shape of historical subjects as they are represented. Before "Ècole des Annales" there was no chance to actualize any research subject apart from public request. Several experiences like works by Leopold von Ranke about history of Papacy didn't shape a new trend before 1920s. But XX century for the first time provided us with the new approach where social order doesn't play significant role. Partly it's because the "New historical science" (the self-entitled methodology by "Ècole des Annales") was created on the joint of various humanitarian studies where standard motivations weren't as important as in history itself: for example, it is impossible to be guided by public request in psychology or sociology. These branches of science deal with actual reality and by default have to keep up to the impartiality.

For the decades and centuries history belonged to the ruling political forces formulating "policy of memory" in each country, and thus shaping the patriotic motivation to ground the publically requested interpretation of the past events.

But what is more important, the influence of "Ècole des Annales" created for the first time discrepancy between public perception of historical events and their correspondence to the past reality reconstructed thoroughly by scientists. For upcoming generations this discrepancy is vital, although not significant for modern historians imbued with the ideas to revive the past, influenced by "Ècole des Annales".

\section{The first close-up and formulation of the problem}

The first obstacle historian encounters is the impossibility to get out of coordinate system including historical events as the ones to influence the future. In this system they are allocated according to their relative significance proved with the further current events. Note that in our everyday life the events are allocated in both public and personal 
perception along the axis which Stephen Hawking called "arrow of time". We never have a full picture of mutual relationship of simultaneous events; we just see the succession. In the science of history we see the subjects of our research differently: some of them have proved their significance for future already and we perceive them as bigger ones. These subjects are called "historical events" and play greater role in shaping down the whole picture of the past.

The scale of historical events makes it necessary to call them in a certain way: to give them identifying name. Some of these subjects historians start to call "wars", although it isn't obligatory coincide with the everyday perception of the event: for instance, Centenary War of 1337-1453 never was a fact for its contemporaries ${ }^{4}$. In their perception it was divided into several military conflicts separated with the periods of peace. Later these periods (evidently important for contemporaries) have been reconsidered non-significant, thus the whole identifying name for the period became "war".

Some of them become "revolutions", although sometimes the usage of this term is anachronistic (Marxist historiography of English history of 1640 - 1660 entitled the events "bourgeois revolution" using the meaning of the term evidently belonging not to XVII but to XVIII century). So, the prominent events in history are never given as themselves but as points on a map which are easy to decipher due to their correspondence to the legend of the map: they are "wars" and "revolutions" to ease our understanding their role for future.

The importance of allocation of historical events plays even greater role. During XX century some concepts of the earlier historiography have been doubted as hardly correspondent to the past reality. For example, the opposition between "Middle Ages" ("Dark Ages") and "Renaissance" (going back to Francesco Petrarch of XIV century) commonplace for European science in XIX century was later negated because of its noncorrespondence to the true events ${ }^{5}$. In spite of it both terms are still in fullfledged usage for they meet fully the needs of historical science to explain the past (although not to revive it).

We would look at the abovementioned structures ("historical events", "historical facts") as at the ones allocated in time but in fact the past

\footnotetext{
${ }^{4}$ Басовская Наталия. Леопард против лилии, Р. 3.

5 Делюмо Жан. Цивилищация Возрождения, Р. 7-8.
} 
reality goes out of hands of historians not only as "time" but also as "space". History by historians is not just a succession of the events; their mutual disposal is more complicated. History for mass consumption and for patriotic usage is much more upright and simplified than for providing further scientific reconstruction. That comes from the fact that patriotic usage doesn't aim to reconstruct the past reality veritably; non-realistic although convincing picture of the past is enough to meet the needs of the society. The source of difference here is that both needs are fulfilled via different exploring procedures: research (in case of scientific usage) and cognition (in case of meeting public request). Only cognition provides the fixation of the events in terms suitable for further usage not only in science but also in the whole sphere of public life (policy, education etc.)

The research deals with subjects; fully explored, they may turn into historical facts (the knowledge of proven and non-disputed verity) ready to live public life even out of history as a science; they start to influence publicity realm. So the interpretative element in the fact isn't important anymore or it may fulfill its role and produces no discussion anymore. The nature of subjects is different; they go on to produce controversy around themselves and thus are not fully prepared to become historical facts.

Saying "subject" we mean historiography because we keep in mind notions like "subject of exploration" or "subject of discussion". Within public life historical facts are required but research subjects aren't; within history as a science both elements are in use for there's no chance to separate correctly "known" facts from subjects still under research. Subject is taken in its totality via look from several points we're going to identify.

Our purpose here is to provide the entire map of structures used by historians in different ways aiming different tasks. We divide them into structures of space and time because all of them get their significance only after their allocation on the scale designed by scientists.

\section{The movability of research subjects in history: chronological and geographical aspects}

The very special feature of historical subjects is their fluent nature. It is represented with their ability to change their limits from time to time due to non-historical influences. The influences usually coming from public request towards history change because of social, cultural, ethnic 
and political matters. French Revolution of XVIII century is a perfect example here. For the French historians the chronological limits of it are between 1789 and 1815 because Napoleonic rule in France dating 17991815 is considered direct continuation of Revolution mostly keeping its influences up; in the USSR Marxist historiography defined chronological limits differently: 1789 - 1794 for Revolution itself and 1799-1815 for Napoleonic rule. Period in between is interpreted as "reaction". The difference derived from the exaggeration of factor of "counterrevolution": Soviet historians didn't discern monarchist counterrevolution in emigration from non-radical revolutionary groups in France. So, here we can see the subject with movable frame and thus with changeable nature perceived in different ways in different national scientific schools.

Some subjects aren't changeable; they are static by their nature. The ones exemplified above are dynamic subjects highly vulnerable to any turns of "policy of memory" and, as a result, changing their limits and nature. Some subjects do not change neither time nor space limits but just their nature. In history of the USA the Civil War of 1861-1865 was considered "rebellion" first; in XX century it became "civil war" finally. The nature of it was interpreted differently too: from the struggle for independence of "nation of Dixie" against "Yanks" to economical fight between highly developed North with growing capitalism and obsolete slave-owning South. Some subjects change chronological limits but territorial ones remain intact. For example, the war for independence of Netherlands against Spain in the late XVI - early XVII century never changed territorial limits as a research subject; however, national historiography defined time frame as 1568-1648 incorporating the events of The Thirty Years War (1618-1648) but excluding the Iconoclastic Uprising of 1566; Marxist historiography included the Iconoclastic Uprising but totally excluded the events of The Thirty Years War making the subject substantially shorter in these limits ${ }^{6}$.

The abovementioned features let us to define the nature of static subjects by commissioning several parameters to verify their changeability:

1) Identifying name;

2) Contents;

\footnotetext{
${ }^{6}$ Чеканов В.Ю. Статичні і динамічні об’єкти в науково-історичному дослідженні, р. 524.
} 
3) Character;

4) Driving forces;

5) Causes;

6) Effects;

7) Meaning.

8) Scale;

9) Chronological limits.

Each of the research subjects may be explored by defining every of these 9 parameters according to the certain historiographical tradition. Then it is possible to discern non-changeable parameters by comparing the appropriate entries of two or more traditions. If so, they may be considered not the intrusions of historiography but the results of true scientific research.

Going back to the Great French Revolution we may try to exercise this research procedure. So, according to the Marxist historiography this revolution is measured in following parameters:

1) Identifying name - the Great French Revolution;

2) Contents - social revolution;

3) Character - bourgeois;

4) Driving forces - bourgeoisie ("the third estate");

5) Causes - crisis of feudalism;

6) Effects - the fall of absolute monarchy, the establishment of capitalism;

7) Meaning - the creation of conditions to promote capitalism;

8) Scale - global;

9) Chronological limits - 1789-1794.

The next task in our analysis is to discern changeable and nonchangeable parameters. The same options should be identified according to non-Marxist historiography where some of them are defined in different way. If any coincide, that means that static parameter is found.

1) Identifying name - the Great French Revolution;

2) Contents - social revolution;

3) Character - bourgeois;

4) Driving forces - bourgeoisie ("the third estate");

5) Causes - crisis of feudalism;

6) Effects - the fall of absolute monarchy, the establishment of capitalism; 
7) Meaning - the creation of conditions to promote capitalism, the establishment of democratic institutions to protect human rights;

8) Scale - global;

9) Chronological limits $-1789-1799$ or 1804 or $1815^{7}$.

As we can see, parameter 7 is widened in non-Marxist historiography; because the important tool to establish democratic institutions was the Napoleon's Code worked out from 1804 to 1811, that leads to changes in parameter 9 (although various scientists define the end of revolution differently: from 1799 to 1815).

The following conclusion may be done: the Great French Revolution as a research subject reveals stability of 7 out of 9 parameters proving it static subject with non-changeable parameters dominating. The inviolable position of the Great French Revolution in history is the cornerstone of the modern epoch and its perception.

Other subjects are more controversial; let's take one entitled "Netherlands bourgeois revolution" in Soviet historiography. According to our algorithm its description will have the next structure:

1) Identifying name - the Netherlands bourgeois revolution;

2) Contents - struggle for national liberation;

3) Character - war for independence, underdeveloped bourgeois revolution;

4) Driving forces - bourgeoisie with national gentry;

5) Causes - braking of Dutch capitalism development by absolutist Spain;

6) Effects - the creation of independent state in the North of Netherlands;

7) Meaning - the acceleration of capitalism development in the North;

8) Scale - local;

9) Chronological limits $-1566-1609^{8}$.

According to this scheme we can trace down some logical contradictions in it: the identification of the process is "bourgeois revolution" although its contents, character and effects (parameters 2, 3, 6) lead us to conclusion that majority of parameters belong to the war for

\footnotetext{
${ }^{7}$ Чеканов В.Ю. Статичні і динамічні об'єкти в науково-історичному дослідженні, р. 522.

${ }^{8}$ Ibid., P. 523-524.
} 
independence. Even if the event is identified as "bourgeois revolution" the social constituent of it is weak however the national one dominates.

The next step is to describe the subject according to contemporary Western historiography. The result will show the following:

1) Identifying name - the Eighty Years War;

2) Contents - struggle for national liberation and Calvinist reformation;

3) Character - war for independence, Calvinist reformation;

4) Driving forces - bourgeoisie, national gentry, Calvinists;

5) Causes - braking of Dutch capitalism development by absolutist Spain, oppression of reformats in Netherlands;

6) Effects - the creation of independent state in the North of Netherlands;

7) Meaning - the acceleration of capitalism development in the North, the victory of Reformation;

8) Scale - local;

9) Chronological limits $-1568-1648^{9}$.

The discrepancy of two research tradition is obvious: the Marxists were prone to underestimate the role of religious factor and to combine the struggle for national liberation with the struggle for freedom to develop local capitalism in Netherlands. The subject is represented differently in two research traditions. It is dynamized by the ideological contradictions. That led to withdrawal of subject from wider contexts (like Reformation and The Thirty Years War) and to the exaggeration of economic factors.

The direct outcome was the drastic re-shaping of chronological limits. The subject changes in Soviet historiography visually: its size decreases but it gets qualitative characteristics of social revolutions (privileged research subjects for historical science in the USSR). At the same time subject's characteristics in Western historiography feature hypertrophying of religious factor and of dynastic and diplomatic fight around the issue of Netherlands independence. This last issue makes it less outstanding in the context of the epoch (the one and only bourgeois revolution in the century) but more involved into usual current of dynastic wars in Europe. The direct result of these processes was instability of the

\footnotetext{
${ }^{9}$ Чеканов В.Ю. Статичні і динамічні об’ єкти в науково-історичному дослідженні. Р. 523-524.
} 
subject and finally non-constituting of "Netherlands bourgeois revolution" as historical fact.

\section{Where it came from: the fundamentals too obvious}

\section{to be spotted at once}

We could trace down the re-shape of research subjects in history while becoming historical facts: they may change not only their nature but also chronological limits. It's quite possible because they didn't exist in the past in the shape we know now: it belongs to historiography fully. The subjects like the row of military conflicts between England and France during XIV - XV centuries weren't perceived by contemporaries as a whole thing; their re-shape into "Centenary war" was made by historiography later. The reason behind this re-shape was the discovery of latent factors behind the events perceived as a succession of wars and truces; pending diplomatic war backing them was never known to the eyewitnesses but for upcoming generations thanks to historians who dismantled the hidden background. The instrument for orientation in the events was the identifying name "Centenary War" to make ready the use of newly identified historical fact for public request.

Such identifying names like "Centenary War" or "Napoleonic Wars" didn't correspond to the perception of humble people of the period; people usually hope to live in peace and think of each pause in the war as of its ending ${ }^{10}$. That is why historical facts hardly correspond to the feeling of contemporaries but they meet the requests of upcoming generations continuing their dialog with the past to fulfill their needs.

The tendentious usage of newly assigned historical facts lets historians format the past according to their convenience or to the public requests historians are urged to meet. The loss of actuality may destroy non-actual identification and lead to the new re-shape of the subject. For example, "Netherlands bourgeois revolution" lost its actuality after decline of communism in the late XX century; the Western identification of the subject - "Eighty Years War" - thusly started to spread all over post-Soviet intellectual space ${ }^{11}$.

All the above mentioned deeds are the expressions of subjective relation to the material of the past; another kind of it is re-location of the

\footnotetext{
${ }^{10}$ Манфред А.3. Наполеон Бонапарт. Р. 357, 373.

${ }^{11}$ Чеканов В.Ю. Ор. cit., p. 525.
} 
events in space and time. The question here is whether any action of historian should cause consequence of such a re-location or it is a result of some subjective attitude of researcher. To get to the point we consider expedient to turn to the oldest historical works of the mankind - to the works of Herodotus (490-425 BC) and Thucydides (460-400 BC).

The "History in nine books" by Herodotus gave the name for a newborn science although the creative approach of its writer hardly looks well acquainted for us. From the very start he drives the reader into wide space and time context including number of foreign countries; the presentation never concentrates just on the past events but involves constantly material from the branches assigned later to ethnology, mythology, cultural history etc. Examining the background of hostility between Greeks and Persians Herodotus discusses it in a context of mutual relationship of Middle East peoples from Lydians to Egyptians ${ }^{12}$. It is understandable as a trick to make the Greek audience more oriented in the entire situation abroad but didn't survive as a research method. The practical use of this method depends upon the level of awareness of audience; the more well-informed is it, the less is the need to provide these "excursions". So the method of Herodotus was perfect for the earliest phase of development of history and that is why it didn't survive upcoming centuries. It still looks unique because it doesn't correspond to the requirements of neither exterior nor interior history constructed later according other models.

Herodotus had to provide certain formatting of his material; his subject was the war between Greeks and Persians; but he couldn't start directly with it omitting the necessity to make his readers know the background. It caused this unique way of story-telling to provide enough introductory information. Later turn directly to the Greek-Persian War resulted into the change of presentation into more upright way.

Because of all these reasons, Greece in Herodotus's work was put into the wide space with number of nations co-existing and fighting. It wasn't an exterior history yet for accent in presentation wasn't made on diplomatic affaires. The features of representation of Greece in "History" by Herodotus are: its functioning in the space of different countries and absence of binary opposition "us - them" in the text. This opposition appeared later when the Greek-Persian War turned out to become the

\footnotetext{
${ }^{12}$ Геродот. История. Р. 3-4.
} 
main topic of the second half of the work. This space allocation of Greece is definitely the result of subjective attitude of the researcher.

The "History" by Thucydides entirely dedicated to the current of allGreek Peloponnesian war (431-404 BC) which greatly impressed Greek society and influenced the further evolution of it. So Thucydides had to deal with the material completely different to the one Herodotus had before his eyes: there was no need to get his audience acquainted with some unknown matters but the public requirement was to make it understand "how it all happened". The events of Peloponnesian war were known to everyone in Greece but the motifs in background of it remained undiscovered. Herodotus had to provide his readers with information; Thucydides had to provide them with understanding.

This difference resulted into more complicated task for Thucydides. To solve it he had to work out the new pattern of story-telling, and it was done. Although the outer influences onto the participants of Peloponnesian war were real the author had to omit them and to concentrate exclusively on interior topics ${ }^{13}$. That led to the change of Greece's representation in space: in Thucydides' work it looks much less involved into international affairs than in "History" by Herodotus. The foreigners arrive into the text of Thucydides not only from abroad but also from the limits of author's vision. That leads to the strong perception that their actions mentioned in the text are voluntary; they are never urged to intrude into the situation unlike Greeks who are fully dependent on causes and consequences of their previous actions. This difference makes binary opposition "us - them" in the text vital; Thucydides even reworks some by-plots surrounding his main topic to make them sound more fitting to the style of entire work. For instance, Trojan War mentioned at the beginning is characterized as the war between Greeks; Thucydides didn't mention the participation of non-Greek peoples in this war on the side of Trojans $^{14}$. It's understandable because Thucydides had to reduce his sources to domestic ones. If Herodotus corrected often his data with foreign versions of events (even in case of Trojan War) ${ }^{15}$, Thucydides never does it strengthening opposition between Greece as the subject of his work and "the whole world" looking at it to intrude in self-serving interest harmful by default.

\footnotetext{
${ }^{13}$ Фукидид. История. Р. 50, 68, 359, 366, 372

${ }^{14}$ Ibid. P. 7-10.

${ }^{15}$ Геродот. Ор. cit. Р. 104-105.
} 
We would say that "History" by Thucydides becomes interior history because it is more patriotic history. The events inside and outside of Greece exist for Thucydides on different levels of perception; this feature influences considerably not only the way of representation of historical material but also the specifics of subjects' allocation in space.

This feature is for the first time put into the center of attention. Up to now we can assert the presence of subjective attitude behind the different types of historical facts' representation. The purpose of it is to equal the levels of representation to some medium one. It enables historical text to perform its mission of information source. In Herodotus's work the task is to put on this level the basic knowledge about Greeks and non-Greek peoples of the East; in case of Thucydides the task is to create the balance between exterior and interior policies' representation saving the atmosphere of all-Greek war influencing every little bit of perception and totally occupying the feelings and attention of Greeks. That is why Thucydides never forgets to underline the political positions of participants of the events ${ }^{16}$.

Another historian to be mentioned here is Polybius hailed for creation of model of description of diplomatic history. His "General history" contains foreword where the writer declares his purpose to depict the story of how Romans managed to take full control over Mediterranean during 53 years only. For Polybius this achievement wasn't preceded by anyone; he calls it "spectacle" underlining impressive side of the process. Polybius interpreted the story of it as "general history" due to the evident outcome: the unification of all known world under one rule ${ }^{17}$.

Polybius was the first history writer to understand the role of composition of the material to strengthen the impression. He got to the point that the presentation part by part causes the loss of the Whole which shouldn't disappear behind the details. To provide this he used the rewriting in short the brief contents of material presented before ${ }^{18}$. The perception of the whole world was strengthened.

So we can discern within the subjective attitude of historian the different purposes: in case of Thucydides they are motivated by political tendency, in case of Herodotus and Polybius they derived from the need to support additionally the representation of material from overseas barely

\footnotetext{
${ }^{16}$ Фукидид. Op. cit., p. 12-13.

${ }^{17}$ Полибий. Всеобщая история. Т. 1. Р. 148.

${ }^{18}$ Ibid., p. 149-150.
} 
known to the audience. However, the need to harmonize the representation of the hard material is traceable in all three works as a prominent feature. It works as a motif driving to choose the certain way of representing the space and time structures. What is also important here is that all three examples of presentation of the material are based upon the feel of space (not time) influencing either virtuoso composition by Herodotus (nearing round by round to the main subject of his work) or kaleidoscopic panoraming of Mediterranean by Polybius or Thucydides' balancing between exterior and interior in his opus magnum.

\section{Medieval developments}

Another obvious subject for analysis belongs to the next epoch usually never praised for its intellectual achievements; medieval period of European history gets a sort of recognition for the narrow chance given to the ancient gems to survive. Only some personalities of the Middle Ages match to the level of the previous period. None of them belongs to historians, what is absolutely understandable: the new generation of historians has chosen the other way of history writing by no means anticipated in ancient period. In short words, the Middle Ages presented the new genre of historical literature: chronicles.

Medieval historians (chroniclers) are numerous and prolific in their output vital for the new (by that time) European nations then and still important for self-identification of these nations. For example, Nestor the Chronicler with his "Tale of Bygone Years" is obligatory to get into history of Kyiv Rus. $\mathrm{He}$ is appreciated as founder of national historiography of Ukraine, or at least as its earliest representative.

What are the peculiarities of their style? By its name it is clear that the cornerstone of their writing was principle of time not space. The attention to time is inherent to the medieval Weltanschauung on whole ${ }^{19}$. It comes from St. Augustine of Hippo whose ideas of ratio between time and eternity penetrated the religious texts of late Roman Christianity. The European chroniclers hardly matched the refinement of his concept but they inherited uprightly the principle of history telling developed in the coordinates of time.

The parallel effect of losing the space feeling is less known although still evident, for instance, in "Chronograph" by Theophanes the Confessor

\footnotetext{
${ }^{19}$ Савельева И. М., Полетаев А. В. История и время в поисках утраченого. Р. 76, 192-196.
} 
(IX century), the famous source of Byzantine history of VIII century. Analyzing his work we can see at once the key features of it. First of all, the typical ancient way of composition of the material (division into "books") is gone; instead, the material is rubricated into sections by years Anno Domini. The events inside each rubric are allocated according to their comparative importance but not according to logic demanding not to interrupt the presentation of certain subject. If Theophanes tells about war with Arabs he never hesitates to interrupt it with the inversion of another subject (if this one would become more important the next year). After having finished this inversion he might return to the previous subject (war with Arabs). The explanation here is that the importance backing these voluntary interruptions inside the whole subject comes from perception of time (not space).

The feel of "importance" of event lying behind this way of composition demands the allocation in time because the comparative significance of the events may be seen from some distance. This distance corresponds fully to the conditions of monastery life (distant by default from any kind of social life) but destroys the logic within events' succession where more and less important events go one by one.

The distant look resulted into the phenomenon of space distortion absolutely "normal" for monks living hermit life and never leaving the walls of monastery. The authors of chronicles feel the time perfectly but lack the adequate feel of space. For example, telling the story about the uprising against emperor Justinian II (705-711) Theophanes describes his military preparations made in Constantinople and his expedition to Sinop (on the southern shore of the Black Sea). By that time the troops of usurper concentrated in Chersoneses (in Crimea, on the northern shore). Being in Sinop the emperor suddenly saw the usurper's fleet going out of Chersoneses to attack Constantinople ${ }^{20}$. This treatment of facts reveals the lack of natural feel of space making the chronicler believe that the look from the southern to the northern shore of the Black Sea (over 500 kilometers) is possible. Theophanes didn't feel the influence of space on the comparative velocity of the events.

Some examples show more complicated way of chronicle composition combining typically medieval approach to time with the feel of space inherited from ancient literature. This can be seen in the oldest

\footnotetext{
${ }^{20}$ Феофан Сигрианский, Исповедник. Хронография.
} 
manuscript of French national historiography "History of the Franks" by Gregory of Tours (VI century). Although Gregory belonged to the same tradition as Theophanes he sounded in his work far more versatile revealing number of influences and tricky combination of it letting him harmonize the presentation. First of all, Gregory uses the foreword technique inherited from Polybius evidently. He uses it to explain the reasons behind his writing and names the decline of "noble sciences" in Gallia as well as desire to bring the memory of past events to the descendants the most important of $\mathrm{it}^{21}$.

The foreword is not just offering to ancient tradition but mostly the occasion to declare himself true Catholic not Arian or Heretic (what was important in the context of epoch). According to this declaration Gregory goes on telling the Holy Story fully in its canonic version (the $1^{\text {st }}$ book of his work covers 5596 years of Biblical history and doesn't come even close to Franks).

The history itself starts from the $2^{\text {nd }}$ book. Gregory expresses openly his writing technique as depending on time. The research purposes sound primitive: to tell about the most important events like people's sufferings and the deeds of the saints ${ }^{22}$. However Gregory uses typically ancient techniques here: he quotes the correspondence between personalities of his chronicle, inserts their speeches etc. The composition of the material recalls ancient approaches: Gregory never drops unfinished subject to turn to another one "of greater importance" and basically observes the plan of each book given at its beginning (what is taken from Polybius again) ${ }^{23}$.

The events never jump from one to another (as in the work by Theophanes), they are united partly by their internal logic, partly by geographical location of them. The observance of logic makes Gregory neglect the chronology of events what is not typical for medieval chroniclers in general. Instead of it Gregory deals perfectly with synchronicity of the events and expresses the tension of it masterfully.

The tendency of the period was contradictory to his manner; the simplified history writing in the style of Theophanes dominated the upcoming centuries. Synchronicity gave in to the diachronic requiring presentation of the material simply year by year. No developments in ideology from VI to IX century happen; the explanation is that changes in

\footnotetext{
${ }^{21}$ Григорий Турский. История франков. Р. 3.

${ }^{22}$ Ibid., p. 24.

${ }^{23}$ Ibid., p. 31.
} 
composition came with the loss of ancient literary culture and corresponded to overall simplicity of "Dark Ages". The intellectual life declined, concentrated exclusively behind the walls of monasteries and it led to the loss of space feel (what has been described before).

\section{The progress of space and time structures' reflection up to date}

The Age of Enlightenment added even more troubles to the historiography. The hypertrophic attention to the subjects of "progressive" meaning caused the perception of their importance a priory and positivity for mankind on whole. If the historians of previous epochs just explored history taking it as a monotonous matter of past (on whole), this situation for the upcoming generation has changed dramatically since then.

The Age of Enlightenment destroyed the integrity of history as a whole thing. If the previous look of the past depended heavily upon the sources and repeated more or less their model of it, new look suggested the possibility of editing past: for instance, to concentrate not on the personality of Julius Caesar (because this concentration is present in all the sources) but on personalities of Brutus and Cassius (because they opposed the dictatorship of Caesar and fought for freedom; this was in trend in the epoch of revolutions).

The past became the material for cuts made by any historian able to justify his own approach; history as science for the first time went out of the field of literature and started to be more creative daring to format the matter of past in the vital interest of present time.

The trend stated above resulted into the situation depicted above: subjects of historical research become movable and dynamic; the title "revolution" has been assigned to the number of them (sometimes reaching up to absurdum like with re-titling the fall of Roman Empire into the "revolution of the slaves" (made by historiography in the USSR) ${ }^{24}$ ). The abovementioned example of Eighty Years War re-titled into "Netherlands bourgeois revolution" is very suitable here too ${ }^{25}$. Eighty Years War pulled a number of European states in; later it became a part of all-European Thirty Years War (1618 - 1648). Formatting of research subjects caused the number of outcomes never anticipated by historians. For example, the re-titling "war" into "revolution" leads to changing

\footnotetext{
${ }^{24}$ Всемирная история. В десяти томах. Т. 3. Р. 73.

${ }^{25}$ Чеканов В.Ю. Статичні і динамічні об'єкти в науково-історичному дослідженні.
} 
research strategy: the war is always double sided matter and involvement of neighboring states is equal. So we should choose the pattern of Polybius to tell the story of war; researching "revolution" we should choose the pattern of Thucydides due to its nature: revolution is national affair and the involvement of neighboring states was never equal.

The subjects like civil wars start to be perceived as integral parts of pairs "revolution - war"; the concept of "revolutionary war" has been worked out recently ${ }^{26}$. Civil wars start to be interpreted as the armed opposition of reactionary classes to the progressive movements embodied in the concept of "driving forces of revolution". Not being put into pair with revolution some wars have been described before just as international military conflicts; from now on the concept of "foreign intervention" becomes actual depiction of situation inside the pair "war - revolution". The fact that some international wars of modern times like wars of antiNapoleonic coalitions against France and war between Austria and Italian states in 1849 have been started under the direct influence of revolutionary events is the irrefutable fact; but this fact became gradually the pattern for historical research of the past times where the usage of it is anachronism. For instance, we call some wars of ancient times "patriotic" or aiming national liberation but we never keep in mind the fact of our being under subconscious influence of modern time's research models: both concepts of "patriotism" and "national liberation" are the brainchildren of modern times. And we say "the uprising of Spartacus" forgetting that Romans called it "the war of Spartacus": concept of "uprising" belongs to our time too and its usage isn't correct concerning previous epochs. However, trying to change it we contradict the needs and understanding of our contemporaries. Here our scientific correctness opposes the viewpoints of society. This situation became actual in XX century because of activity of French "Ècole des Annales".

\section{CONCLUSIONS}

So the research made above provides us with a number of conclusions enabling to outline in general the features of gradual development of evolution of space and time structures' reflection in the European tradition of historiography:

\footnotetext{
${ }^{26}$ Чеканов В.Ю. Суб'єктивне розташування війн та революцій в історичному часі. Р. 76.
} 
1) The reflection of space and time structures is immanent to the historiography from the very start of European tradition of history writing. It is present in the earliest examples of it represented in the works by Herodotus, Thucydides and Polybius;

2) The reasons of it are linked with the needs either to correspond to the special requirements of the material or to meet the public requests and expectations from the history writers;

3) The crucial changes in the European tradition of historiography occur in the Age of Enlightenment; they are connected with the inception of the new research subjects like revolutions and revolutionary wars. Since then the tradition to re-shape the entire picture of the certain epochs or historical process in general has been put into practice widely;

4)Depending upon the correspondence to public requests the research subjects in history may show out abilities to change their meaning while re-shaping their chronological and geographical limits (in other words, their space and time characteristics); the ones demonstrating high instability may be considered dynamic subjects, and the ones more stable and resistible to these requests may be considered static.

5) The reflection of space and time structures in historiography is thusly the inherent feature of historiographical rework on the past reality; it is versatile motivated and expressed procedure absolutely necessary to represent past reality in scientific activity of historians.

\section{SUMMARY}

The article deals with rarely touched issue of basic backgrounds of historical science: the reflection of space and time structures in historiography affecting the composition, character and possibly the message put into the research work. Explored on examples of ancient and medieval authors - contemporaries of the first attempts to work out the standard of space and time structures' reflection - the article shows how the various approaches to the issue developed enriching each other and gradually drove to the formation of basic genres of scientific historiography. The connections between historiography and historiosophy are explored as well. The article is devoted to the yet undiscovered problem, so the conclusions are to be continued in further exploration. 


\section{REFERENCES}

1. Басовская Наталия. Столетняя война: леопард против лилии. М.: Астрель, 2007. 446 с.

2. Всемирная история. В десяти томах / гл. ред. Е.М. Жуков. М. : Гос. изд-во политической литературы, 1957. Т. 3.896 с.

3. Геродот. История в девяти книгах / пер. Г.А. Стратановского. М.: ОЛМА-ПРЕСС Инвест, 2004. 436 с.

4. Григорий Турский. История франков / пер. В.Д. Савуковой. М.: Наука, 1987. 350 с.

5. Делюмо Жан. Цивилизация Возрождения. Екатеринбург : У-Фактория, 2008. $720 \mathrm{c}$. $680 \mathrm{c}$.

6. Манфред А.З. Наполеон Бонапарт. Сухуми: Алашара, 1989.

7. Полибий. Всеобщая история / отв. ред. А.Я. Тыжов. Т. 1. СПб. : Наука, 2005. 496 с.

8. Савельева И. М., Полетаев А. В. История и время в поисках утраченого. М. : Языки русской культуры, 1997. 800 с.

9. Фукидид. История / [изд. подг. Г.А. Стратановский, А. А. Нейхард, Я. М. Боровский]. Л. : Наука, 1981. 543 с.

10. Февр Люсьен. Бои за историю. М. : Наука, 1991. 632 с.

11. Феофан Сигрианский, Исповедник. Хронография - читать, скачать // Азбука веры. Православная библиотека. URL: www.azbuka.ru/

12. Хёйзинга Йохан. Осень Средневековья. СПб. : АзбукаАттикус, 2018. 720 с.

13. Чеканов Всеволод. Статичні і динамічні об'єкти в науковоісторичному дослідженні. Наукові записки Інституту украӥнської археографії $i$ джерелознавства імені М.С. Грушевського НАН Украӥни. Т. 20. 2010. С. 517-528.

14. Чеканов В.Ю. Суб'єктивне розташування війн та революцій в історичному часі. Вчені записки Таврійського національного університету імені B.I. Вернадського. Серія "Історичні науки". T. 29 (68). № 2. 2018. C. 74-78.

Information about the author: Chekanov V. Yu.

Candidate of historical sciences, Assistant professor of the department of philosophy and history, Taurida V.I. Vernadsky National University,

33 Ivana Kudri str., Kyiv, Ukraine 